\title{
Improving the quality of installation of preinsulated pipelines of heat supply systems
}

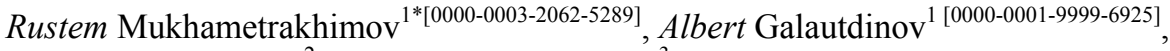 \\ Anastasia Panchenko ${ }^{2}$ and Tatyana Gorbunova ${ }^{3}$ \\ ${ }^{1}$ Kazan State University of Architecture and Engineering, Kazan, Russia \\ ${ }^{2}$ Ingstroy, LLC, Kazan, Russia \\ ${ }^{3}$ Kazan State Academy of Veterinary Medicine named after N.E. Bauman, Kazan, Russia
}

\begin{abstract}
One of the most important directions of Russia's economic and energy strategy is to increase the efficiency in the field of heat supply. One of the options for solving this issue is using preinsulated pipelines, such as steel pipes in polyurethane foam polyethylene insulation. The experience of their application indicates several disadvantages associated with defects in pipes in polyurethane foam insulation and installed pipelines. The studies carried out made it possible to identify the main defects and inconsistencies in the manufacture and installation of preinsulated pipelines and the reasons for their occurrence. Following this, the authors have developed a set of operations and control tools during the installation of pipes in polyurethane foam PE insulation, clarifying the requirements of the input, operational and acceptance types of control, which contribute to improving the quality of the finished product, which was the purpose of this work.
\end{abstract}

\section{Introduction}

Increased energy saving and energy efficiency requirements contribute to the introduction of new materials and technologies into construction practice, which can significantly reduce the consumption of energy and material resources during the operation of permanent and linear construction facilities and improve their quality [1-3]. An analysis of the implementation of Russia's energy strategy for the period up to 2020 shows that the use of low-quality thermal insulation materials in the process of central heating networks building is one of the main problems of energy conservation. Up to the date, the implementation of the energy strategy for the period up to 2020 cannot be considered satisfactory, since the heat losses of the central heating system have not been reduced by $60 \%$, the production of heat energy has been increased for 34\% [4]. This is confirmed by statistics [4], indicating an increase in the depreciation of the centralized heat supply fund from $65 \%$ to $70 \%$ since 2010 and the need for major repairs or complete replacement of $82 \%$ of heating networks. Moreover, their actual heat loss is $30 \%$ for the present moment. In this regard, one of the most important areas of economic and energy policy in Russia is to improve efficiency in the field of heat supply.

\footnotetext{
*Corresponding author: muhametrahimov@mail.ru
} 
Analysis of literature data indicates an active study of the issues of improving the production, installation and operation $[12,13]$ of pipelines in polyurethane foam $\mathrm{PE}$ insulation [14-16]. The positive experience of pipelines maintenance in polyurethane foam PE insulation in Germany and Denmark should be noted [17]. The works [18-21] show the discrepancy between the standard and calculated heat energy losses for different types of pipe insulation. Studying the quality control system during the construction of external water supply and sewerage systems is studied in the present work [22]. The issues of optimization of the thickness of polyurethane foam insulation of pipelines in heat supply systems were studied by the authors in the works $[9,23]$.

The production process of pipes in polyurethane foam PE insulation includes the following technological operations: primary control of raw materials and materials; the processing of steel pipes and fittings; installation of centering rings made of low-pressure polyethylene (HDPE) and copper wire ORMS; installation of a steel pipe into a PE pipe; installation of filling plugs on the ends of pipes; preliminary thermostatic treatment of the assembled pipe structure to improve the adhesion of polyurethane foam to the steel pipe; dosing and feeding of PPU components through the plug hole; quality control of manufactured products; marking of finished products with accompanying documentation; transfer of finished products to the warehouse.

The presence of quality control in the manufacture of pipes in polyurethane foam PE insulation does not exclude the occurrence of defects, which indicates the need to analyze and systematize them to improve production efficiency, which is one of the tasks of this work.

Installation of pipes with polyurethane foam PE insulation includes the following stages: pipes surface conditioning from insulation at a distance of up to $300 \mathrm{~mm}$ from each edge, making a welded joint of pipes, completing with a heat shrink sleeve, filling the cavity under the sleeve with polymer, followed by heating and settling the sleeve in place, ensuring the tightness of the outer sheath. Pipes with polyurethane foam PE insulation are welded following GOST 30732-2001( Russian National State Standard).

Failure to comply with the installation technology, namely the sealing and insulation of joints when installing pipes with polyurethane foam PE insulation, leads to a violation of insulation in the most vulnerable places of any pipelines - the joints of the pipe and the shaped element. The result of this will be the occurrence of premature external corrosion of the pipe [24], a decrease in durability [25], followed by the failure of the pipeline or carrying out constant expensive repair work [26, 27].

The performed analysis indicates the need to carry out research to identify pipe defects in polyurethane foam PE insulation formed during the manufacturing and installation process, and the reasons for their occurrence, with the subsequent development of the composition of operations and control means during their installation, which is the purpose of this work.

One of the options for solving this issue is the use of preinsulated pipelines in the central heating system, such as steel pipes in polyurethane foam (PPU) polyethylene (PE) insulation [5,6], including the use of resource-saving polymer compositions [7]. Their use will significantly reduce the time and specific damage of pipelines and increase the efficiency of construction of linear facilities compared to the traditionally used channel pipelines using mineral wool [8-10].

The advantage of steel pipes in polyurethane foam PE insulation is the presence of an operational remote monitoring system (ORMS), which ensures timely identification of facts and places of defects occurrence, which makes it possible to reduce heat carrier losses, increase its energy potential and, as a result, reduce heat energy costs. However, it should be noted that this system has disadvantages due to inaccurate determination of the place of depressurization of the PUF cover layer and the area of distribution of this process [11]. 


\section{Methods}

The object of the present research are pipelines in polyurethane foam PE insulation, manufactured in the factory and having a multilayer structure "pipe in pipe" [28, 29] (Figure 1).

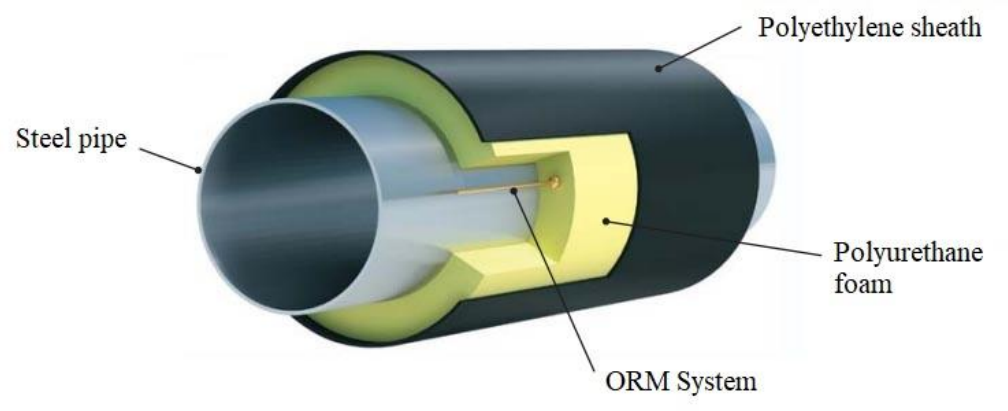

Fig. 1. Elements of the pipeline in polyurethane foam insulation

As internal pipes, we used hot-deformed round steel pipes for general purposes following Russian National Standard 8732-78, longitudinal electric-welded pipes following Russian National Standard 10705-80, longitudinal welded steel pipes following Russian National Standard 20295-85. As outer pipes, protective shells made of HDPE are used following Russian National Standard 18599-2001, Russian National Standard 16338-85.

Polyurethane foam insulation is a two-component system consisting of polyol and polyisocyanate, applied by pouring a liquid substance into the tube space of steel and polyethylene pipes.

The subject of the research is the quality control system for manufacturing and installation of pipelines in polyurethane foam PE insulation. At the first stage of the research, the analysis of the technical condition and energy efficiency of the existing central heating networks was carried out; the technologies for the manufacturing and installation of pipes in polyurethane foam insulation, the issues of improving the production of pipelines, improving the quality of their installation and operation, the relationship between defects and thermal characteristics of buildings were studied. Analysis and generalization as the research methods were applied.

At the second stage, by the method of visual and instrumental control, the study of pipes in polyurethane foam PE insulation at the manufacturing plant and at the construction site during installation was carried out. By the method of systematization, their main defects and damages revealed in the process of manufacturing and installation were classified.

At the third stage, using the obtained quantitative data on the defects types and the reasons for their occurrence, the authors systematized the quality control requirements for the manufacturing process and installation of pipes in polyurethane foam PE insulation.

To determine the geometric deviations, a set for visual and measuring control was used $[22,30]$, which included a steel ruler, caliper with a depth gauge, a testing square, etc.

\section{Results and Discussion}

The most typical defects and the reasons for their occurrence, which occur during the production of pipes in polyurethane foam PE insulation, are shown in Table 1 and Figure 2. 
Table 1. Defects and the causes of their occurrence revealed during the manufacturing of pipes in polyurethane foam PE insulation.

\begin{tabular}{|l|l|}
\hline \multicolumn{1}{|c|}{ Defect title } & \multicolumn{1}{|c|}{ Possible causes } \\
\hline $\begin{array}{l}\text { Inconsistency of the wall thickness of steel } \\
\text { pipes in polyurethane foam PE insulation } \\
(108 \times 5 \mathrm{~mm}-\text { fact } 108 \times 4 \mathrm{~mm})\end{array}$ & Violation of incoming quality control \\
\hline $\begin{array}{l}\text { Peeling of polyurethane foam from the } \\
\text { steel pipe and/or from the shell }\end{array}$ & $\begin{array}{l}\text { Violation of the technology: the polyethylene shell } \\
\text { did not go through the coronation process; } \\
\text { mechanical stress during transportation }\end{array}$ \\
\hline Remote monitoring system does not work & $\begin{array}{l}\text { Internal break in copper wire; Touching the copper } \\
\text { wire against the wall of the steel pipe inside the } \\
\text { polyurethane foam; copper wire does not meet the } \\
\text { requirements of Russian National State Standard }\end{array}$ \\
\hline $\begin{array}{l}\text { The thickness of the polyurethane foam } \\
\text { layer does not comply with Russian } \\
\text { National State Standard 30732-2006 }\end{array}$ & $\begin{array}{l}\text { Technology violation: the diameter of the PE shell- } \\
\text { pipe is not accepted correctly }\end{array}$ \\
\hline $\begin{array}{l}\text { Misalignment of steel and polyethylene } \\
\text { pipes }\end{array}$ & $\begin{array}{l}\text { Technological violation: the use of centering } \\
\text { supports of the wrong size }\end{array}$ \\
\hline $\begin{array}{l}\text { Increased porosity, brittleness of } \\
\text { polyurethane foam at the ends of pipes }\end{array}$ & $\begin{array}{l}\text { Violation of technology, inadequacy of the quality } \\
\text { of the materials used }\end{array}$ \\
\hline $\begin{array}{l}\text { The length of non-cast ends of steel pipes } \\
\text { exceeds the permissible values }\end{array}$ & $\begin{array}{l}\text { Error when choosing the length of the polyethylene } \\
\text { sheath }\end{array}$ \\
\hline
\end{tabular}

The analysis of the results given in Table 1 indicates the need to supplement the operations and controls scope during the installation of the pipes under study, shown by the authors in Table 3 .

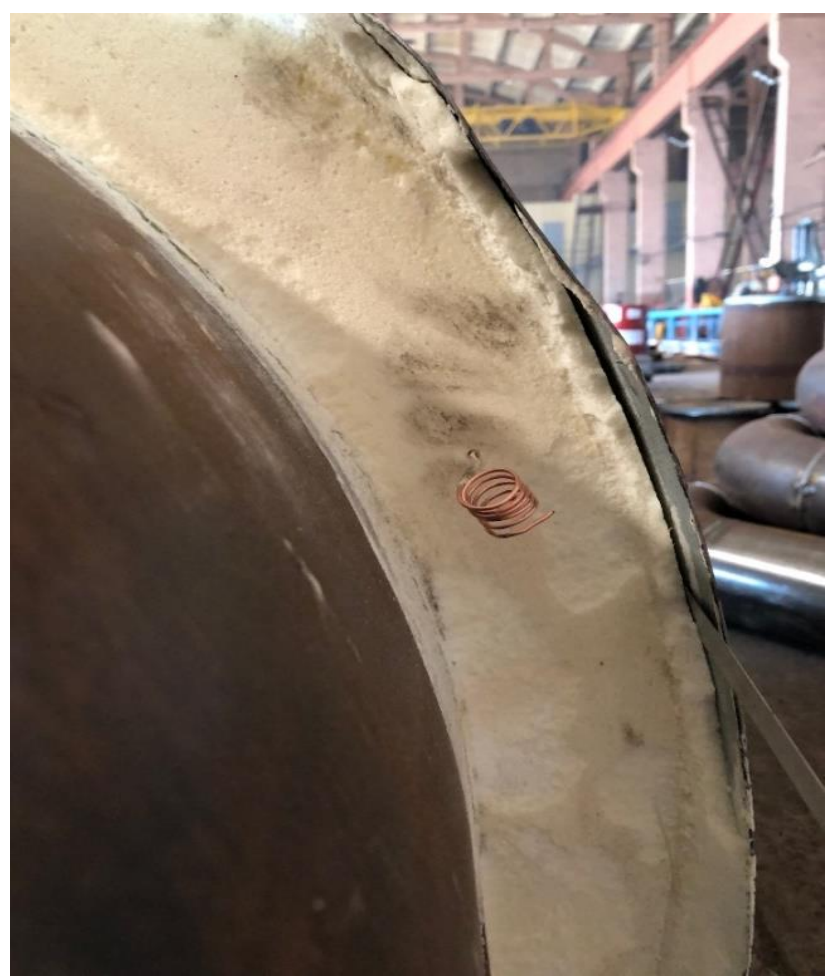

Fig. 2. Peeling of polyurethane foam from the polyethylene shell 
Systematization of pipes defects and damages in polyurethane foam PE insulation during their installation is shown in Table 2.

Table 2. Defects and damages revealed during the installation of pipes in polyurethane foam PE insulation

\begin{tabular}{|l|l|}
\hline \multicolumn{1}{|c|}{ Defect title } & \multicolumn{1}{|c|}{ Cause of occurrence } \\
\hline Lack of product labeling & $\begin{array}{l}\text { Violation of the technological process in the } \\
\text { production of pipes; deliberate removal of } \\
\text { markings }\end{array}$ \\
\hline $\begin{array}{l}\text { Scratches, roughness of the polyethylene shell } \\
\text { of pipes in polyurethane foam insulation }\end{array}$ & $\begin{array}{l}\text { Violation of the rules of transportation, loading } \\
\text { and unloading operations }\end{array}$ \\
\hline Cracking on the surface of polyethylene pipes & $\begin{array}{l}\text { Violation of storage rules; violation of the rules of } \\
\text { loading and unloading operations; the use of } \\
\text { polyethylene of an inappropriate grade (Russian } \\
\text { National State Standard 30732-2006) }\end{array}$ \\
\hline $\begin{array}{l}\text { The thickness of the thermal insulation of } \\
\text { fittings does not correspond to the thickness of } \\
\text { the thermal insulation of pipes }\end{array}$ & $\begin{array}{l}\text { Error when choosing the diameter of the } \\
\text { polyethylene shell of pipes and fittings }\end{array}$ \\
\hline $\begin{array}{l}\text { Soaking of polyurethane foam at open ends of } \\
\text { pipes }\end{array}$ & Violation of storage rules \\
\hline Lack of tightness of the pipeline & Defects of welded seals of steel pipes \\
\hline $\begin{array}{l}\text { Difficulty mounting the heat-shrinkable sleeve } \\
\text { on the pipe }\end{array}$ & $\begin{array}{l}\text { Non-conformity of the sleeve diameter, violation } \\
\text { of storage rules }\end{array}$ \\
\hline Remote monitoring system does not work & $\begin{array}{l}\text { Violation of installation rules: incorrect connection } \\
\text { or broken wires }\end{array}$ \\
\hline
\end{tabular}

The analysis of Table 2 shows that the cause of the above-mentioned defects and damages are violations of production and installation technology and violations of quality control during construction and installation works. On this basis, the authors have systematized the requirements for quality control of the manufacture and installation of pipes in polyurethane foam PE insulation (Table 3), ensuring compliance with the production technology and improving the quality of finished products. 
Table 3. Scope of operations and means of control during the installation of pipes in polyurethane foam PE insulation

\begin{tabular}{|c|c|c|c|}
\hline $\begin{array}{l}\text { Stages of } \\
\text { work }\end{array}$ & Controlled operations & $\begin{array}{l}\text { Control (method, } \\
\text { scope) }\end{array}$ & Documentation \\
\hline \multirow{5}{*}{ 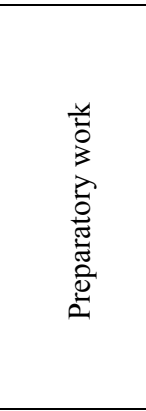 } & \multicolumn{2}{|c|}{ Check: } & \multirow{5}{*}{$\begin{array}{l}\text { Passports, } \\
\text { certificates, } \\
\text { general work log }\end{array}$} \\
\hline & $\begin{array}{l}\text { availability of a quality document for } \\
\text { materials, tags, labels, markings on pipes; }\end{array}$ & Visual & \\
\hline & $\begin{array}{l}\text { quality control of supplied pipes: wall } \\
\text { thickness, ORMS wires, pipe integrity, } \\
\text { polyurethane foam, etc. }\end{array}$ & $\begin{array}{l}\text { Measuring, } \\
\text { technical inspection }\end{array}$ & \\
\hline & $\begin{array}{l}\text { availability of a quality document for } \\
\text { materials, tags, labels, markings on pipes; }\end{array}$ & Visual & \\
\hline & $\begin{array}{l}\text { quality control of supplied pipes: wall } \\
\text { thickness, ORMS wires, pipe integrity, } \\
\text { polyurethane foam, etc. }\end{array}$ & $\begin{array}{l}\text { Measuring, } \\
\text { technical inspection }\end{array}$ & \\
\hline \multirow{5}{*}{ 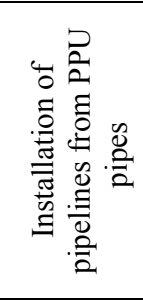 } & \multicolumn{2}{|c|}{ Control: } & \multirow{5}{*}{ General work log } \\
\hline & $\begin{array}{l}\text { quality and sequence of installation of PPU } \\
\text { pipes; }\end{array}$ & $\begin{array}{l}\text { Technical } \\
\text { inspection }\end{array}$ & \\
\hline & quality of welded joints of steel pipes; & Measuring & \\
\hline & $\begin{array}{l}\text { coincidence of the thickness of thermal } \\
\text { insulation of fittings and pipes }\end{array}$ & Visual & \\
\hline & $\begin{array}{l}\text { working condition of remote monitoring } \\
\text { system }\end{array}$ & Measuring & \\
\hline \multirow{3}{*}{ 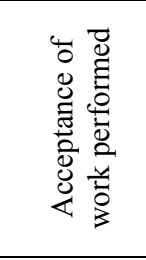 } & \multicolumn{2}{|l|}{ Check: } & \multirow{3}{*}{$\begin{array}{l}\text { General work log, } \\
\text { act of acceptance of } \\
\text { work performed, } \\
\text { executive scheme, } \\
\text { test report of } \\
\text { pipelines }\end{array}$} \\
\hline & the quality of the work performed; & $\begin{array}{l}\text { Measuring, } \\
\text { technical } \\
\text { inspection }\end{array}$ & \\
\hline & testing of pipelines; & $\begin{array}{l}\text { Measuring, } \\
\text { technical } \\
\text { inspection }\end{array}$ & \\
\hline \multicolumn{4}{|c|}{ Control and measuring tool: level; density meter, thickness meter, flaw detector } \\
\hline \multicolumn{4}{|c|}{ Input and operational control is carried out by foreman } \\
\hline \multicolumn{4}{|c|}{$\begin{array}{l}\text { Acceptance control is carried out by quality service workers, foreman (foreman), representatives } \\
\text { of the customer's technical supervision }\end{array}$} \\
\hline
\end{tabular}

Control tools have been developed to install pipes in polyurethane foam PE insulation, clarifying the requirements of the input, operational and acceptance types of control, contributing to the improvement of the quality of the finished product [31].

The performed studies can be useful in carrying out studies to improve the quality of pipelines in polyurethane foam PE insulation as part of the implementation of a strategy for increasing energy efficiency and reliability of central heating networks.

\section{Conclusions}

1. The performed analysis of literature data indicate the need to improve the efficiency of central heating systems, to carry out research to identify defects in the manufacture and installation of pipes in polyurethane foam PE insulation, the reasons for their occurrence, followed by the development of the composition of operations and controls during their installation.

2. The technology of production and installation of pipes in polyurethane foam PE insulation has been studied, the main technological processes of production and installation of pipes are given. The decline in the quality of manufacture and installation of pipes in 
polyurethane foam PE insulation is revealed. It is shown that the causes and damages of the defects are violations during the execution of technological processes of manufacturing, transportation, storage and installation of preinsulated pipes.

3. The composition of operations and control means for the installation of pipes in polyurethane foam PE insulation based on the identified defects formed during the manufacture and installation of pipes, and the determination of the causes of their occurrence, which will improve the quality of installation of preinsulated pipelines and the efficiency of heat supply systems has been developed.

\section{References}

1. Mukhametrakhimov, R.Kh., Khuzin, AF, Khamidullina, DD: Features of the technology of the device and quality control of monolithic steel-fiber-concrete floors using void-formers. Izvestia of the Kazan State University of Architecture and Civil Engineering, 3, pp. 228-235 (2018)

2. Mukhametrakhimov R.K., Lukmanova L.V., Kamaliev M.I .: Features of the quality control system when installing hinged ventilated facade systems. Izv. KGASU. 43,pp. 234-240 (2018)

3. Mukhametrakhimov R.Kh. Aliullova I.R. Improving the quality control system for the device of expansion joints with a rubber compensator during the repair of bridge structures. Izvestia of the Kazan State University of Architecture and Civil Engineering, 3, pp. 47-55 (2020)

4. Pavlova D.V. Analysis and research problems of district heating pipes with preliminary insulation from PPU and PPM, Modern scientific research and innovation. 5, pp. 70-76 (2016)

5. Kononova M.S., Zherlykina M.N., Kononov A.D. Substantiation of a Choice of Construction of the Thermal Networks in Monolithic Isolation of Polyurethane. In: IOP Conference Series: Materials Science and Engineering (2018), https://doi.org/10.1088/1757-899X/463/2/022045.

6. Dolgova A.N., Yunak S.A., Rudenko A.S., Haibullina A.I., Karataeva E.S. Comparative efficiency of pipeline heat-insulating materials. IOP Conf. Ser. Mater. Sci. Eng, 915, (2020), https://doi.org/10.1088/1757-899X/915/1/012010.

7. Galeev R., Nizamov R., Abdrakhmanova L., Khozin V, Resource-saving polymer compositions for construction purposes. In: IOP Conference Series: Materials Science and Engineering (2020), https://doi.org/10.1088/1757-899X/890/1/012111.

8. Baybakov S.A. Timoshkin, AS: The main directions of increasing the efficiency of heating networks. Power stations, pp.19-25 (2004)

9. Shcherbak, AS: Investigation of the properties of modern thermal insulation materials. Science and progress of transport, Bulletin of the Dnipropetrovsk National University of Railway Transport 2, pp.136-143 (2013)

10. Nalobin N.V. Optimization of the thickness of polyurethane foam insulation of heat pipelines in heat supply systems of facilities in the north of Western Siberia, (2007)

11. Golubkov S.K. Experience in the operation of pipes in polyurethane foam insulation with a system of operational remote control (ODK). In: Heating networks, Modern solutions, pp. 1-4 (2005)

12. Harders V. Earth-laid preinsulated bonded pipe HT systems, (2004)

13. Wang T., Li H.W. Insulation failure judgment method of rigid polyurethane foam insulating layers on buried pipelines, Corros. Prot, (2010)

14. Alencastro J., Fuertes A., de Wilde P. The relationship between quality defects and the thermal performance of buildings, (2018), https://doi.org/10.1016/j.rser.2017.08.029.

15. Cherchi C., Badruzzaman M., Oppenheimer J., Bros C.M., Jacangelo J.G. Energy and water quality management systems for water utility's operations: A review, (2015). https://doi.org/10.1016/j.jenvman.2015.01.051.

16. Karathanasi I., Papageorga kopoulos C. Development of a Leakage Control System at the Water Supply Network of the City of Patras. In: Procedia Engineering (2016), https://doi.org/10.1016/j.proeng.2016.11.100.

17. Korolev I.A, Petrakov G.P: Creation of a test center for testing the quality of polyurethane foam insulation of preinsulated pipelines used in heat supply systems. Engineering and construction journal, pp. 23-25 (2011)

18. Kovalevsky V.B. Energy efficiency of channelless heating networks, Heat supply news. pp. 40- 
43 (2010)

19. Kovalevsky V.B. About standard heat losses during channelless laying of heat pipelines. Heat supply news,pp. 24-27 (2001)

20. Kovalevsky V.B., Petukhov B.C. Technical and economic indicators of heat-insulated pipes for heating networks of channelless laying. Heat supply news, 6, pp. 18-26 (2003).

21. Polovnikov, V.Y .: Thermal regimes and thermal losses of underground pipelines in real heat exchange on the outer interaction boundary. Bull. Tomsk Polytech. Univ. Geo Assets Eng, (2018)

22. Mukhametrakhimov, R.Kh., Panchenko, AA: Study of the features of the quality control system during the construction of external water supply and sewerage networks. Izvestia of the Kazan State University of Architecture and Civil Engineering, 4, pp. 360-367 (2017)

23. Slepchenok, VS, Petrakov, GP: Improving the energy efficiency of thermal insulation of pipelines of heating networks in the northern and northeastern regions of Russia. Engineering and construction journal, 4, pp. 26-32 (2011)

24. Kim, J.G., Kim, Y.W., Kang, M.C .: Corrosion characteristics of rigid polyurethane thermally insulated pipeline with insulation defects. Corrosion. (2002). https://doi.org/10.5006/1.3277318

25. Kayumov R.A., Suleymanov A.M., Muhamedova I.Z. Estimation of the durability of polymer composites on a fabric basis, taking into account the influence of non-force factors. In: IOP Conference Series: Materials Science and Engineering (2020), https://doi.org/10.1088/1757899X/934/1/012041

26. Banushi G., Vega A., Weidlich I., Yarahmadi N., Kim J., Jakubowicz I., Sällström J.H.: Durability of District Heating Pipelines Exposed to Thermal Aging and Cyclic Operational Loads. J. Pipeline Syst. Eng. Pract. (2021), https://doi.org/10.1061/(asce)ps.1949-1204.0000521

27. Mukhametrakhimov R.Kh., Panchenko A.A. Features of manufacturing technology, installation and quality control of pipelines in polyurethane foam PE insulation. Izv. KGASU, 44, pp. 246254 (2018). Freeman R. Predicting and qualifying the long-term behaviour of polyurethane foam in sob-sea pipe-in-pipe systems. In: 16th International Conference on Pipeline Protection (2005)

28. Mollison M.I. Pipe-in-pipe insulation system passes tests for reel lay. Oil Gas J. (1992).

29. Panchenko A.A., Mukhametrakhimov R.Kh. Galautdinov A.R.: Quality control during the construction of external water supply and sewerage networks. In: Resursoenergoeffektivnyie tehnologii v stroitelnom komplekse regiona. pp. 43-46, (2018).

30. Masatin V., Volkova A., Hlebnikov A., Latosov E.: Improvement of District Heating Network Energy Efficiency by Pipe Insulation Renovation with PUR Foam Shells. In: Energy Procedia (2017), https://doi.org/10.1016/j.egypro.2017.04.064. 